\title{
Handling Innovation in Small Family Firms: The Role of Context
}

\author{
Michela Floris ${ }^{1}$, Angela Dettori ${ }^{1} \&$ Cinzia Dessi ${ }^{1}$ \\ ${ }^{1}$ Department of Economics and Business Sciences, University of Cagliari, Italy \\ Correspondence: Angela Dettori, Department of Economics and Business Sciences, University of Cagliari, Italy. \\ E-mail: angela.dettori@unica.it
}

Received: January 9, 2020

doi:10.5539/ijbm.v15n5p60
Accepted: March 31, 2020

URL: https://doi.org/10.5539/ijbm.v15n5p60

Online Published: April 14, 2020

\begin{abstract}
Innovation management in family firms is a paradoxical challenge. The constant tension between innovation and tradition confers to this topic a fascinating mystery area that calls to action scholarly efforts and further studies to underscore whether family firms are innovating or not. This debate becomes even more intriguing and interesting when family businesses are small-sized and embedded in local contexts strongly attached to traditions and cultures that inhibit change. Based on the curiosity of analyzing the innovation proclivity of small family firms rooted in such a context and building on previous studies that were focused on innovation in family run businesses, we deeply investigated two cases. Findings uncovered a twofold and opposite role of the context: on the one hand, a constraint and, on the other hand, leverage of innovation. Interesting scholars and practical implications are discussed, and future studies are suggested.
\end{abstract}

Keywords: innovation, family firms, contextual level

\section{Introduction}

Several studies have revealed that family firms are reluctant to introduce innovations that generate change in the business (Sharma \& Manikutty, 2005). Sometimes, contrary to the general notion, later generations are more conservative than previous ones (De Massis, Chirico, Kotlar, \& Naldi, 2014) due to a strong attachment to tradition and family-produced goods (De Massis et al., 2014). In addition, recent studies (Duran, Kammerlander, Van Essen, \& Zellweger, 2016) have shown that family firms are more engaged in incremental rather than radical innovation due to lower proactiveness. Other studies (Kammerlander, Dessì, Bird, Floris, \& Murru, 2015) found that innovative spirit can be influenced by the stories told across generations, which affect the way in which family members manage their firm, by tracing innovative or conservative paths.

The literature, in this sense, seems to be split into two main branches. On the one hand, family firms appear to be conservative and, on the other hand, family firms are engaged in relevant innovative activities (Zahra, 2012), pursuing achievement, seeking overseas markets, introducing innovations and following risky strategies. This apparent incongruence needs in-depth analysis to understand why some family firms clearly demonstrate an innovation propensity, while others remain conservative, inflexible, and risk-averse (Chrisman \& Patel, 2012), and to discover the main elements that affect family firms' innovation strategies. Specifically, inspired by a recent study (Bettinelli, Sciascia, Randerson, \& Fayolle, 2017) we consider the contextual and individual elements as the main exogenous and endogenous drivers that encourage or discourage innovation and entrepreneurial orientation within small family firms.

By participating in this ongoing debate, this paper focuses on two exemplary cases of small family firms embedded in a very particular context with the aim of underscore the role that this context plays in managing innovation.

\section{Theoretical Background}

\subsection{Innovation in Family Firms}

As competitive pressures increase, all types of organizations seek innovations to compete and survive in the market (Kleinschmidt \& Cooper, 1991; Dieleman, 2019). Innovation can be defined as "an idea, practice, or object perceived as new by an individual or other unit of adoption" (Rogers, 1995, p. 35) and, in small or family businesses, it depicts the ability to alter the paths of the past and develop something that is "new to the firm" (Hage, 1999). Family firms, in fact, are generally imagined to be entities that adhere to traditions and resist 
change (Kammerlander et al., 2015; Dacin, Dacin \& Kent, 2019; Erdogan, Rondi \& De Massis, 2019).

For family firms, being innovative means increasing the chance of flourishing across generations (Zellweger, Nason, \& Nordqvist, 2012; Ingram, Lewis, Barton, \& Gartner, 2014; Jaskiewicz, Combs, \& Rau, 2015; Diaz-Moriana, Clinton, Kammerlander, Lumpkin, \& Craig, 2018; Dacin et al. 2019), thus several studies have investigated which factors affect innovation in family firms. Many of them have positive and/or negative effects, such as for instance the availability of resources (König, Kammerlander, \& Enders, 2013), the loyalty among employees (Duran et al., 2016) or the competency of successors (Litz \& Kleysen, 2001). Moreover, the flexibility of organizational structures (Craig, Dibrell, \& Davis, 2008), the professionalization of management (Alfredo De Massis, Frattini, Kotlar, Petruzzelli, \& Wright, 2016), the strategic behavioral controls (Hsu \& Chang, 2011), the existence of a long-term perspective (Diaz-Moriana et al., 2018;) and the intensity of R\&D (Sciascia, Nordqvist, Mazzola, \& De Massis, 2015), represent other elements that trace different family firm's innovative behavior. Differences among family firms in pursuing innovation are linked with the avoidance or acceptance of challenges and changes (Sciascia, Mazzola, \& Chirico, 2013; De Massis, Wang, \& Chua, 2019), often motivated by an excessive dependence on the firm's past (Zahra, Hayton, Neubaum, Dibrell, \& Craig, 2008), that can sometimes generate inertia and difficulties in facing competitors (Jaskiewicz et al., 2015). In fact, resistance to innovation is due to a strong attachment to the founder and/or family imprinting (Kammerlander et al., 2015) and/or to the context variables that affect family firm innovativeness (i.e. Bettinelli et al., 2017).

In this sense, a combination of endogenous (internal) and exogenous (external) aspects determines the firm's propensity for or resistance to innovation. In particular, in small family firms embedded in particular contexts, the family owner (at the individual level) and the territorial characteristics (that comprise the contextual level) have relevant weight in stimulating or restraining innovation. For this reason, an analysis of these two drivers appears particularly relevant, especially for small family firms that must manage innovation to survive across generations in closed or narrow markets or in areas characterized by unfriendly socio-economic and geographical aspects.

\subsection{The Relevance of the Contextual Level}

The contextual level refers to the "place" where a firm is embedded; it involves the geographical aspects, the effects of time, socio-economic elements, industry, sources, norms, culture, traditions, and a whole other set of aspects that influence the origins, forms, functioning and varied results of innovative initiatives (Ucbasaran, Westhead, \& Wright, 2001; Zahra \& Wright, 2011; Ramadani \& Hoy, 2015; Botella-Carrubi \& Gonzàlez-Cruz, 2019).

The context has a significant influence on the existence and dynamics of firms, in terms of growth, development, survivability, and innovation propensity. Nevertheless, there is still no clarity as to how this influence occurs (Phan, 2004; Davidsson, 2006; Autio \& Acs, 2010; DiazMoriana et al., 2018). A focus on this influence deserves special attention because, as emphasized by Hayton, George, and Zahra (2002), firms reflect their nearby environments and want to gain and maintain context legitimacy (Hayton et al., 2002) to survive, as well as earn local recognition, appreciation and support. Context legitimacy is particularly relevant for family businesses, as stated by Gianni Agnelli, the head of the Fiat Group, at the world convention of family firms in 2001:

Having roots in a community, in its culture, in its values, is an essential aspect of a family firm's identity. These roots guide our behaviors and entrepreneurial decisions, with attention and a sense of responsibility toward the community, its problems and its expectations for growth. This attention and sense of responsibility cannot be detached from the paramount duty of the owners to stay competitive. Because staying competitive is the premise and precondition of any social function of the firm. Constantly striving to strike a balance between the highest level of competition and integration with the local and national territory is another integral aspect of the family firm (Corbetta \& Salvato, 2012).

The main contextual elements for small family firms in seeking legitimacy can be delineated as follows: a. the variable "time," which influences the ability to identify and exploit opportunities (Short, Ketchen, \& CL, 2010) and which helps bind families with past strategies (Zahra, 2006); b. the development of various industries, related and unrelated (Zaheer, \& A, 1999); c. spatial dimensions, characterized by the geographical location (Clark, Feldman, \& Gertler, 2006); the morphology, institutions and demographic aspects of the population (Saxenian, 1994); and d. the social and cultural dimensions (Hayton et al., 2002; Russell, 2005; Thornton, Ribeiro-Soriano, \& Urbano, 2011; Ramadani et al., 2017). In the present study, the most relevant contextual factors are represented by institutional, spatial and cultural aspects; this is in line with Stough, Welter, Block, Wennberg, and Basco (2015) who identified these aspects as exogenous elements that drive the creation of family businesses and their evolution (Basco, 2015). In sum, managing a small family firm is not merely an 
economic process but instead, one that draws from many contextual elements. As part of the local structure, family firms can identify innovation opportunities (Jack \& Anderson, 2002; Dacin et al. 2019).

Thus, the contextual factors may support or invalidate the embeddedness phenomenon, which is essential to a firm's survival. Consequently, the context must be taken into account because it constitutes a vital resource for small firms, especially family-owned businesses; embeddedness offers firms the 'unique' potential, to create long-term relationships with local stakeholders, to transmit a perception of trust and credibility, to preserve the family reputation, and to ensure a competitive advantage (Upton, Teal, \& Felan, 2001; Ramadani \& Hoy, 2015; Mani \& Durand, 2019).

\subsection{The Role of Individual Level}

Sharma \& Chrisman (1999) argue that family members are the driving force of family firms, and their personal capabilities represent the foundation of entrepreneurial orientation (Joardar \& Wu, 2011; Sieger \& Minola, 2017) This suggests that individual family members directly affect firm performance (Chrisman, Chua, \& Litz, 2003) by sustaining the firm in special and unique methods that influence innovation and other entrepreneurial outcomes (Tagiuri \& Davis, 1996; Dacin et al. 2019). In line with this statement, the individual level as an endogenous driver of innovation because it sets the patterns of personal capacities, attitudes, perceptions, characteristics, perspectives and ambitions of the family members (Joardar \& Wu, 2011; Reay, 2019) that directly influence the performance of the firm (Chrisman et al., 2003) and the perception of opportunities. In fact, the awareness of external and internal environmental stimuli and events represents the filters used in making decisions (Behrens \& Patzelt, 2016) and the force in implementing innovation strategies. Moreover, family business owner-managers tend to consider the firm as part of the extended self (Furby, 1978); strong psychological feelings of ownership can provide a foundation for innovative behaviors (Brown, Brown, \& Perkins, 2004; Dacin et al. 2019).

Therefore, different methods of managing innovation depend primarily on the members of the family firm and their ability to capture the essence of the context in which the firm is embedded. In fact, researchers have stated that family members' interpretation of contextual factors is the cornerstone of innovation and the entrepreneurial orientation of family firms (Zahra, 1991; Sieger \& Minola, 2017), especially in very small entities (Wiklund, 1998). In addition, as suggested by Hollander and Bukowitz (1990) and Hollander and Elman (1988), a business's culture is often an embodiment of the founder's personality and it influences the characteristics of the firm's development and its ability to respond to contextual changes. A firm will have an internal orientation toward innovation (Zahra \& Sharma, 2004; Erdogan et al., 2019) if it is inherent in the founder's personality (Kelly, Athanassiou, \& Crittenden, 2000). This internal orientation drives the firm's evolution by following the founder's intuition, ideas and strategies (Cruz \& Nordqvist, 2012).

Such centrality, generally, tends to reduce the shift in management to the second generation, when decision-making is more a shared process (Carney, 2005; Reay, 2019). In this phase, new owners are often called in to revitalize and further expand the inherited family firm (Hoy, 2006). The new approach considers more than the past and the context; the internal cultural orientation is combined with a fresh external orientation that considers context signals as a source of long-term survival (Hoy, 2006).

\section{Methodology}

A qualitative methodology is chosen for this research, executed through the analysis of two case studies. Family firms represent a fertile ground for qualitative analysis (Litz, 1997; McCollom, 1990), and is particularly appropriate for this study because of the focus on family businesses' innovation, a topic with debate and contrary findings (Suddaby, Bruton, \& Si, 2015). This research is in line with recent qualitative studies that have analyzed the "traditional" way of promoting innovation (Bouette \& Magee, 2015; Kuhn \& Galloway, 2015; Pret \& Cogan, 2018; Ramadani, Hisrich, Dana, Palalic, \& Panthi, 2017). Moreover, the use of case studies allows for an analysis of real, unique phenomena, observing the particular scenario and its interactions within the boundaries of context in which it develops and acts (Patton, 1990; Yin, 2008). It represents a form of qualified investigation aimed at seeking the "meaning" of reality in the experiential experience of people and organizations (Eisenhardt, 1989; Eisenhardt \& Graebner, 2007; Patton, 1990; Yin, 2008). A comparison of two case studies is particularly useful in this work to spotlight innovative behaviors in two small family firms from the same territory. This is in line with Patton's (1990) recommendation. The objects are two Italian firms, operating in the traditional bakery sector. The narrative approach has been used for data collection and analysis, supplemented by additional sources for data triangulation (Jick, 1979; Jonsen \& Jehn, 2009).

\subsection{The Narrative Analysis}


A narrative analysis (Dawson \& Hjorth, 2012; Gartner, 2007, 2010) is an interpretive approach that helps to understand human behavior (Cope, 2005). It examines people in the process of generating and transferring knowledge (Lyotard, 1984). This approach stimulates the generation of in-depth and contextualized empiric evidence (Bansal \& Corley, 2011) that conceptualizes phenomena and their processes and extends existing theories (Johansson, 2004) or creates new ones.

This methodology has been used in several studies of innovation and entrepreneurship that consider the relevance of the owner (Hamilton, 2006a, 2006b; Hjorth \& Steyaert, 2004; Johansson, 2004; Larty \& Hamilton, 2011), A narrative approach highlights existing correlations such as the link between events and behavior (Czarniawska, 1997b). Studying the processes of a family business through a narrative approach means to participate in the social dynamics of relational constructs, such as roles, resources, projects, organizations, and objectives, and verifying the way an owner family defines the company's development paths in relation to the family's history (Labaki, Bernhard, \& Cailluet, 2019).

In this work, following the suggestions of Czarniawska (1997a; 1997b, 1999, 2004), the analysis was conducted using the hermeneutic trio (Hernadi, 1987), which conceptually highlights three phases: 1) explication, i.e., contextualization, reconstruction and synthetics, and history; 2) explanation, i.e., identification, description and understanding the meaning of the narrative; 3) exploration, i.e., discussion of what emerged in the previous stages and identification of the implications. In addition, to highlight congruencies and inconsistencies, the stories were analyzed through the dramatist approach (Burke, 1985), which recommends clearly highlighting the reference context, the stories, the sequence of events, the main actors, how actions are carried out, and the motivations behind the actions.

\subsection{The Contextualization}

The objects of this study are two small family firms located in Italy, in a region that is among the 65 poorest in Europe characterized by low density, a negative natural growth rate, a high retirement index, which highlights the considerable presence of older people, compared to the young population. Both case firms operate in the same local territory, characterized by a declining resident population and a negative natural balance, particularly in recent years. The gradual depopulation of the territory includes a continuing decline in the working population, and generational changes in the world of work, while in terms of education the area is in line with regional data. The economy is mostly primary and tertiary industries, with few businesses in the secondary sector. The rate of firm development is negative, and firms encounter considerable difficulties in survival and development, due to multiple causes, the combination of which makes the area one of the poorest in Italy.

In light of this brief context description, it can be argued that the area appears to be unfriendly and infertile for firm development and it represents a challenge for firms that aim to survive across generations staying embedded in the local territory. This is especially true for firms involved in traditional industries, such as the artisanal bakery sector. Bread is a symbol of history and cultured transferred across generations, in particular from women's hands and minds. Bread makers jealously protect and transmit knowledge orally from generation to generation within families. Families share a dense and endless network of narratives, sharing centuries of history to bring bread, to families' tables. The oral tradition and unique output denote the importance of transgenerational shift, moving baking from homes into an entrepreneurial activity for the market. In this region, the main bakery companies are family-owned and intergenerational. These small entities use a traditional production process and sell their products locally. Although some small family firms are starting to introduce innovation in their production and products, each bakery preserves its aromas, its tastes, its rites, and its symbols. This particular evocative and personal sense that bread embodies stimulates reflection, especially when referencing the role of innovation in such a traditional sector. In order to investigate these dynamics, the narratives of two-family entrepreneurs have been listened to, recorded, transcribed and analyzed. These stories offer interesting insights into understanding whether innovation represents a deliberate strategy or a "necessity" to surviving in unfriendly local contexts.

\section{The Case Studies}

To ensure anonymity and guarantee privacy, the two small family firms are labeled as Firm A and Firm B, and respondents' real names are not used.

\section{Firm A}

Firm A was founded in 1954 and is in the second generation. There are nine family members that are actively engaged in the firm, with different roles. In the last three years, revenues increased by $11.61 \%$. Of its market, $25 \%$ are regional customers and $75 \%$ are in other regions of Italy and foreign markets (Europe, America, Asia and 
Australia).

The founder worked as a shepherd until the age of nineteen when he was invited by a friend to acquire his bakery in a big city. He stayed close to this city, where he met his current wife and started his big family.

In 1973, in a small village, a famous local baker invited the founder to take over his bakery and he happily accepted. In that period, he managed two bakeries: the first, in a big city and the second, in a small village. They were in two different areas, with different cultures and economies, and far apart and difficult to manage. For this reason, the founder decided to invest all of his efforts into the small village operation. Starting with the production of daily fresh bread to sell to the surrounding area, the founder's entrepreneurial spirit manifested. He introduced a traditional type of bread, typically handmade only by women in their homes. Initially, the only difference between domestic production and bakery production was quantity. Immediately the wife, capturing a nascent market requirement, began offering the pistoccu in packs of one kilogram, packaged in specially printed envelopes. This idea, veering from past paths, sanctioned the sale of the packaged product and immediately registered the first successes in terms of pistoccu demand and market expansion.

Firm A was the first mover in producing and selling a product traditionally handmade by the families; as a son said: "In the 70s, the product began to be packaged, and with great convenience, it was possible to expand the market and distribute a product with a longer life that allowed it to be marketed in a wider range." In light of the growing demand, the founder and his family decided to implement production and develop new product lines. At first, the production included only whole-wheat flour; then, also thanks to packaging, it was possible to diversify production and use both white flour and whole-wheat flour. These strategies represented a first turning point in the history of the company: from a strictly local market, they moved to a wider market. For this reason, Firm A needed to acquire new plants and buildings. The passion for bread-making activity immediately "contaminated" the entire family. The children were introduced at an early age into the family business, helping their parents in the production and selling. The official entrance of the second generation happened at the end of the 1990s, starting a new era for the firm, full of innovation and new strategy implementation. One son, in particular, represented the heart of the firm's revolution. Thanks to participation in international and national fairs, he created an important network with giants of organized distribution and the product started to be appreciated overseas. "For us, it was an opportunity for confrontation with the rest of the world and rapid growth," the son stated. Their success implied a long series of product innovation, with the introduction of modern equipment and high technology machinery compliant with hygiene and safety standards. The generational shift represented a milestone in Firm A's history.

The small family firm showed an innovative spirit, thanks to the founder's charisma, but the new generation impressed a real change for the firm: from a local firm to an international firm. In fact, during the last two decades, Firm A has considerably strengthened its presence in both the national and international markets, increasing production lines, promoting diversification, and differentiating, while above all, interpreting the traditional bread of the region in innovative ways to meet international tastes. The history of Firm A is characterized by a progressive and constant orientation toward the future, characterized by a real desire for growth that stimulated the next generation to increasingly broaden its horizons, crossing the sea to the rest of Europe Australia, America, and even China.

\section{The territorial context}

Firm A operates mainly in the national and international markets. However, this does not mean that geographical location represents an advantage for the company. A son states, "Our territory is isolated, especially in winter, when it takes just a bit of snow to send all the transport in the area into a tailspin." He added, "A problem that goes beyond the isolation of our territory is the absence of local carriers that push to reach other areas of the island...It would be a business opportunity for many subjects and could guarantee improvement for all the producers in the area." A further weakness, as pointed out by a son is "the absence of warehouses for the storage of products."

Another son clarifies: "Our problem as a firm is not so much tied to the shipment of goods as to their entry. Since there are no incoming goods, transport is much more expensive and often there is difficulty in finding a carrier that is available only if the journey is fully loaded. Probably, solving the logistic problem is the key to allow the development of our marginal area. In fact, if an unexpected event occurs, it is necessary to postpone the transport for a week and this negatively affects customer relations. Punctuality of service is rewarded in this sector, as is the quality of the product. Not guaranteeing it, you are penalized".

The geographical location and the problems of logistics represent difficulties. Another son does not see the resolution logistic problems as a driving force for success: "Despite all the logistical difficulties, I believe that 
there must be a willingness on the part of all the entrepreneurs in the area to cooperate and join forces. We are still far from this culture of collaboration. ...Internationalization strategies are not simple to implement, but we invest our efforts to do this. However, in these last years, we have noted that probably only the regional market needs to receive our attentions. For the future, we intend to reinforce our presence also in the region because we think that our product represents our isle around the world, and then it is important having also its local legitimization". The son concludes sharing a dream: "If we worked together [referring to their competitors], as good colleagues, we would be able to do our best. We are trying it. We take part in many partnership initiatives and slowly many others are joining. The network and mutual collaboration represent the main bridges to the world, able to overcome all the problems, even those related to our geographical position".

Firm B

Firm B is a young small family firm, founded in 2005 and is also in the second generation; four family members are actively involved in different roles. In the last three years, revenues have increased by $21 \%$. The market is divided as follows: $90 \%$ local and $10 \%$ other regions of Italy.

The main aim of Firm B is to preserve and to consolidate the ancient tradition of baking a traditional local bread. A son, a member of the second-generation states: "My parents started making the typical bread because my father was unemployed. He had another job, but to keep the family going he had to get involved and, together with my mother, he invented a new job. The production was intended mainly for friends, relatives, and acquaintances. In addition, with this system, they went on until my father found another job and I decided to run my own business, with a new impulse toward the market. The founders, however, are my parents and still support us and give us a big hand".

When Firm B was founded, the founder was unemployed following the bankruptcy of his company. To find an alternative source of income for his family, he decided to take advantage of the wood-burning oven built by his father in the 1980s in the basement of their home. With his wife, he created the basis for a new activity, the production of traditional bread for friends and neighbors. Starting this initiative without employees, the founder immediately involved his children. After school or in their free time, they helped out, soon learning the meaning of hard work, commitment and, above all, the knowledge and skills necessary to make carasau bread. At the beginning of 2000, after completing his studies and graduating from a technical and commercial institute, the first son, joined the family business. A few years later, in 2002, the founder found a new stable occupation and drastically reduced his time in the bakery. However, despite the reduced commitment of the founder, the firm did not close, and the first son ran the firm, taking on the responsibilities of the business owner. This young boy, enthusiastic and creative, had clear ideas: he did not want a bakery like his competitors, oriented exclusively to distributing bread outside the territory. He aspired primarily to obtain strong legitimacy in his own territory and worked right away to obtain an appreciation of his product in his homeland.

To understand what improvements were needed, he began to study local competition and concluded that processes, usually based on excessive automation and an industrial approach (to reduce time and the rationalize production costs), affected the purely artisanal aspect of the product and the characteristics of a qualitative nature. He was interested in the craftsmanship art of the product; he wanted to capture customers' attention with reference to the quality of the product. Thus, he preserved the use of the wood-fired oven and engaged in the careful selection of raw materials of unquestionable quality; all aspects of the processing followed the traditions of making the traditional bread.

A few years later, another son joined the small family firm, and since the market was growing slowly, encouraging innovation. He introduced machinery for specific stages of the production process, careful to preserve the artisanal process.

Today, Firm B still operates in the historic factory built by the founder and his wife; it is a small workshop where, with the help of two employees, produces various types of carasau bread. The classic line, which is the most appreciated, is also the biggest seller. Three other product lines were introduced later and packaged differently; they constitute innovative interpretations of the traditional bread. Only excellent local raw materials are chosen, from stone-ground wheat to sourdough, and the processes are traditional from leavening in linen and cotton sheets to baking in a wood-burning oven, in order to guarantee a strict artisan processing.

For a few months, at the request of another bakery, they experimented with the production of an innovative interpretation of the traditional bread, but this idea was soon abandoned to avoid the firm losing its identity, which was built with difficulty over time. Customers were beginning to associate this new product with Firm B and this did not correspond to the image conceived by owners. 
The meticulous care that the family dedicates to the production of its "special bread" allows it to create a high-quality product with absolute respect for tradition. The family's commitment has received special recognition and the bakery has won several awards over the years for the best traditional bread and bakery products.

Future projects include the construction of a new laboratory to carry out the processing of classic carasau bread with state-of-the-art machinery and an electric tunnel oven for increased production. This is a move to widen the firm's market boundaries, perhaps even build commercial relationships with large-scale retailers. The historic wood-burning oven, which references the first generation, will not be abandoned; instead, it will be entirely dedicated to the production of special lines, because it is considered the true strength of the bakery, differentiating it from competitors.

\section{The territorial context}

Firm B's prevailing interest is staying in the regional market, which represents $90 \%$ of its sales. The other $10 \%$ is concentrated in other Italian areas, usual restaurants. The small local size of the market allows Firm B to serve customers using only personal vehicles, delivering bread once a week. To handle foreign deliveries the firm employs specialized couriers that take care of everything, from the collection of the goods to their delivery. In fact, as a son pointed out "Usually, deliveries are made by me over the weekend, on Saturdays with the company van. For other deliveries, I call the couriers, who are specialized in this sector. On the fact that we are isolated, there is no doubt, even for the mere fact that for us it is necessary to cross the sea and therefore it is not possible to compete with other Italian bakeries. Fortunately, we only make our typical bread here and therefore we do not have much competition in this field."

\section{Discussion}

The two small family firms involved in this research exhibit several differences in facing innovation challenges and in considering innovation as a way to increase the firm's activities and competitiveness. However, they have two common elements: 1) the unfavorable context in which they are embedded, poor, marginal, difficult to serve with infrastructures and transport, with a narrow market and very ancient and strong tradition and culture; and 2) the sector in which they operate-bakeries-that even if traditional and rooted in the local culture, need constant innovation to guarantee success. Notwithstanding, both firms are resilient, able to meet customer needs and work to ensure survivability across generations.

Innovation is encapsulated in the firms' strategies in different ways. It has been mainly introduced to make product and process changes and improvements to satisfy the firms' intentions and goals. Moreover, the firms have shown different paths during the lifecycle. Firm B has underlined an unusual behavior. During its lifecycle, Firm A has shown a physiological innovation propensity, in line with Sharma, Chrisman, \& Chua (2003): the second generation represents change and leaving the traditional path but referencing to past strategies and development trails. Moreover, although Firm A is undoubtedly innovative, the things the family owners have introduced are not cutting edge, that is, radical or revolutionary, but rather are incremental. This is in line with the findings of Nieto, Santamaria, and Fernandez (2015). What is particularly interesting is that Firm A, thanks to product and process innovation, has become an international firm able to meet consumers' preferences and take risks in a sector that, often, calls to mind the image of a small neighborhood bakery. Actually, it is a very innovative small family firm, which constantly studies how to respond to the expectations of customers all over the world and is able to offer different product lines and many variations to the market. This firm, in addition, has not abandoned tradition, but has undoubtedly innovated in scale and shape; it is a visionary in the development of new products that recall the regional tradition but meet international preferences. The life of Firm $\mathrm{A}$ is characterized by a continuous tension between tradition and innovation. On the one hand, the older generation was particularly attached to the past and uncertain about the strategies implemented by the new generation. On the other hand, the new owners are very motivated, curious, and risk-oriented; they are convinced that innovation is not equivalent to abandoning established practices, but to a functional review with a view to transgenerational growth and survival. Local context, in this case, represents contemporarily an obstacle because of the unfriendly environment as a springboard to reaching new and more ambitious goals overseas.

Firm B has shown an unusual development trajectory. It was interested in innovating its products by ensuring adequate processes, but in a certain instance, the owners have reversed their strategies to focus on traditional products, not altering the very ancient nature of the carasau. This is in line with Duran et al. (2016) who noted the link with context and that consolidating past paths affects innovation propensity. Product innovation comes in the form of a new line of products, but they are not really finding innovative ways to conceive the traditional product. High quality represents the main specific character of the Firm B products; it unceasing searches for 
high quality raw materials. However, it is anchored to tradition. Process innovation is introduced only to alleviate manual hard work and not to increase production to enlarge the bakery's markets. The owners' goal is preserving the artisanal nature of the process. This case appears to be following the "innovation through tradition" strategy (De Massis et al., 2016), in which innovation allows a firm to reinterpret existing traditions that characterize the core of the local context.

\section{Conclusions}

The two small family firms have shown two different approaches to innovation strategies. Each of them, in their lifecycle, has introduced product and process innovations, generally incremental in nature. However, the owners' goals have strongly affected innovation propensity. Firm A is managed by a particularly ambitious second generation, who is passionate and interested in growing and selling in international markets because the local context is too narrow for their aspirations. It is characterized by a low dynamism. Firm B is managed by a second generation that expresses the desire to obtain trust in the local context, trying to differentiate its product from that of competitors by using high quality raw materials. The dream of Firm A is to become a leader in the local context. Considering the weakness of the market and the unfriendly local context as cornerstones to stay and think local, its innovations continually reference tradition. Both small firms are seeing a constant increase in their revenues; this allows us to suppose that each strategy gains positive results. Consequently, what is the right innovation strategy in an unfriendly context? Is it innovating and thinking global or is it "retro-innovating" and thinking local? In other words, is innovation a deliberate strategy or a "must" for survival in unfriendly local contexts? The firms analyzed have shown that innovation can be interpreted through different perspectives and lenses, with reference to the owners' aims. Firm A considers innovation as a deliberate strategy to be competitive in the international market, while Firm B sees innovation as a "must" to survive in the local unfriendly context and clearly respects local tradition.

These findings have highlighted that for small family firms, the role of the individual level is relevant in overcoming context difficulties, shifting the obstacles in opportunity for growing locally or globally. Further studies should be carried out in longitudinal and cross-case analyses to determine what happens in other sectors, regions and over a firm's lifecycle. Moreover, it would be interesting to study the differences between family and non-family firms that operate in a similar setting.

\section{References}

Autio, E., \& Acs, Z. (2010). Intellectual property protection and the formation of entrepreneurial growth aspirations. Strategic Entrepreneurship Journal, 4(3), 234-251. https://doi.org/10.1002/sej.93

Bansal, P., \& Corley, K. (2011). The coming of age for qualitative research: Embracing the diversity of qualitative methods. Academy of Management Journal, 54(2), 233-237. https://doi.org/10.5465/amj.2011.60262792

Basco, R. (2015). Family business and regional development-A theoretical model of regional familiness. Journal of Family Business Strategy, 6(4), 259-271. http://doi.org/10.1016/j.jfbs.2015.04.004

Behrens, J., \& Patzelt, H. (2016). Corporate Entrepreneurship Managers' Project Terminations: Integrating Portfolio-Level, Individual-Level, and Firm-Level Effects. Entrepreneurship Theory and Practice, 40(4), 815-842. https://doi.org/10.1111/etap.12147

Bettinelli, C., Sciascia, S., Randerson, K., \& Fayolle, A. (2017). Researching Entrepreneurship in Family Firms. Journal of Small Business Management, 55(4), 506-529. https://doi.org/10.1111/jsbm.12347

Botella-Carrubi, M. D., \& Gonzàlez-Cruz, T. F. (2019). Context as a Provider of Key Resources for Succession: A Case Study of Sustainable Family Firms. Sustainability, 11(1873), 1-18. http://doi.org/10.3390/su11071873

Bouette, M., \& Magee, F. (2015). Hobbyists, artisans and entrepreneurs: Investigating business support and identifying entrepreneurial profiles in the Irish craft sector. Journal of Small Business and Enterprise Development, 22(2), 337-351. https://doi.org/10.1108/JSBED-02-2013-0022

Brown, G., Brown, B. B., \& Perkins, D. D. (2004). New housing as neighborhood revitalization: Place attachment and confidence among residents. Environment and Behavior, 36(6), 749-775. https://doi.org/10.1177/0013916503254823

Burke, K. (1985). Dramatism and logology. In D. L. Sills (Ed.), International encyclopedia of the social sciences (pp. 445-452). London, UK: Macmillan Publishers.

Carney, M. (2005). Corporate governance and competitive advantage in family-controlled firms. 
Entrepreneurship Theory and Practice, 29(3), 249-265. https://doi.org/10.1111/j.1540-6520.2005.00081.x

Chrisman, J. J., \& Patel, P. C. (2012). Variations in R\&D investments of family and non-family firms: Behavioral agency and myopic loss aversion perspectives. Academy of Management Journal, 55(4), 976-997. https://doi.org/10.5465/amj.2011.0211

Chrisman, J. J., Chua, J. H., \& Litz, R. (2003). A unified systems perspective of family firm performance: An extension and integration. Journal of Business Venturing, 18(4), 467-472. https://doi.org/10.1016/S0883-9026(03)00055-7

Clark, G., Feldman, M., \& Gertler, M. (2006). The Oxford Handbook of Economic Geography. Oxford, UK: Oxford University Press.

Cope, J. (2005). Researching entrepreneurship through phenomenological inquiry: Philosophical and methodological issues. International Small Business Journal, 23(2), 163-189. https://doi.org/10.1177/0266242605050511

Corbetta, G., \& Salvato, C. (2012). Strategies for longevity in family firms: A European perspective. New York: Palgrave Macmillan.

Craig, J. B., Dibrell, C., \& Davis, P. S. (2008). Leveraging family-based brand identity to enhance firm competitiveness and performance in family businesses. Journal of Small Business Management, 46(3), 351-371. https://doi.org/10.1111/j.1540-627X.2008.00248.x

Cruz, C., \& Nordqvist, M. (2012). Entrepreneurial orientation in family firms: A generational perspective. Small Business Economics, 38(1), 33-49. https://doi.org/10.1007/s11187-010-9265-8

Czarniawska, B. (1997a). Narrating the organization: Dramas of institutional identity. Chicago, IL: University of Chicago Press.

Czarniawska, B. (1997b). A narrative approach to organization studies. Thousand Oaks, CA: Sage.

Czarniawska, B. (1999). Writing management: Organization theory as a literary genre. Oxford, UK: Oxford University Press.

Czarniawska, B. (2004). Narratives in social science research. Thousand Oaks, CA: Sage.

Dacin, M. T., Dacin, P. A., \& Kent, D. (2019). Tradition in organizations: A custodianship framework. Academy of Management Annals, 13(1), 342-373. https://doi.org/10.5465/annals.2016.0122

Davidsson, P. (2006). Nascent entrepreneurship: empirical studies and developments. Foundations and Trends in Entrepreneurship, 2(1), 1-76. https://doi.org/10.1561/0300000005

Dawson, A., \& Hjorth, D. (2012). Advancing family business research through narrative analysis. Family Business Review, 25(3), 339-355. https://doi.org/10.1177/0894486511421487

De Massis, A., Chirico, F., Kotlar, J., \& Naldi, L. (2014). The Temporal Evolution of Proactiveness in Family Firms: The Horizontal S-Curve Hypothesis. Family Business Review, 27(1), 35-50. https://doi.org/10.1177/0894486513506114

De Massis, A., Frattini, F., Kotlar, J., Petruzzelli, A. M., \& Wright, M. (2016). Innovation through tradition: Lessons from innovative family businesses and directions for future research. Academy of management perspectives, 30(1), 93-116. https://doi.org/10.5465/amp.2015.0017

De Massis, A., Wang, H., \& Chua, J. H. (2019). Counterpoint: How heterogeneity among family firms influences organizational change. Journal of Change Management, 19(1), 37-44. https://doi.org/10.1080/14697017.2017.1419808

Diaz-Moriana, V., Clinton, E., Kammerlander, N., Lumpkin, G., \& Craig, J. B. (2018). Innovation motives in family firms: A transgenerational view. Entrepreneurship Theory and Practice, 1-32. https://doi.org/10.1177/1042258718803051

Dieleman, M. (2019). Reaping what you sow: The family firm innovation trajectory. Journal of Famili Business Strategy, 10(4), 1-12. https://doi.org/10.1016/j.jfbs.2018.03.003

Duran, P., Kammerlander, N., Van Essen, M., \& Zellweger, T. M. (2016). Doing more with less: Innovation input and output in family firms. Academy of Management Journal, 59(4), 1224-1264. https://doi.org/10.5465/amj.2014.0424

Eisenhardt, K. M. (1989). Building theories from case study research. Academy of Management Review, 14(4), 
532-550. https://doi.org/10.5465/amr.1989.4308385

Eisenhardt, K. M., \& Graebner, M. E. (2007). Theory building from cases: Opportunities and challenges. Academy of Management Journal, 50(1), 25-32. https://doi.org/10.5465/amj.2007.24160888

Erdogan, I., Rondi, E., \& De Massis, A. (2019). Managing the tradition and innovation paradox in family firms: A family imprinting perspective. Entrepreneurship Theory and Practice, 44(1), $20-54$. https://doi.org/10.1177/1042258719839712

Furby, L. (1978). Possessions: Toward a theory of their meaning and function throughout the life cycle. In P. B. Baltes (Ed.), Life-span development and behavior (Vol. 1, pp. 297-336). New York, NY: Academic Press.

Gartner, W. B. (2007). Entrepreneurial narrative and a science of the imagination. Journal of Business Venturing, 22(5), 613-627. https://doi.org/10.1016/j.jbusvent.2006.10.003

Gartner, W. B. (2010). A new path to the waterfall: A narrative on a use of entrepreneurial narrative. International Small Business Journal, 28(1), 6-19. https://doi.org/10.1177/0266242609351448

Hage, J. T. (1999). Organizational innovation and organizational change. Annual Review of Sociology, 25, 597-622. https://doi.org/10.1146/annurev.soc.25.1.597

Hamilton, E. (2006a). Narratives of enterprise as epic tragedy. Management Decision, 44(4), 536-550. https://doi.org/10.1108/00251740610663063

Hamilton, E. (2006b). Whose story is it anyway? Narrative accounts of the role of women in founding and establishing family businesses. International Small Business Journal, 24(3), 253-271. https://doi.org/10.1177/0266242606063432

Hayton, J. C., George, G., \& Zahra, S. A. (2002). National culture and entrepreneurship: A review of behavioral research. Entrepreneurship Theory and Practice, 26(4), 33-52. https://doi.org/10.1177/104225870202600403

Hernadi, P. (1987). Literary interpretation and the rhetoric of the human sciences. In J. S. Nelson, A. Megill, \& D. N. McCloskey (Eds.), The rhetoric of the human sciences (pp. 263-275). Madison, WI: University of Wisconsin Press.

Hjorth, D., \& Steyaert, C. (2004). The prosaic of entrepreneurship. In D. Hjorth \& C. Steyaert (Eds.), Narrative and Discursive Approaches in Entrepreneurship (pp. 8-21). Cheltenham, UK: Edward Elgar.

Hollander, B. S., \& Bukowitz, W. R. (1990). Women, family culture, and family business. Family Business Review, 3(2), 139-151. https://doi.org/10.1111/j.1741-6248.1990.00139.x

Hoy, F. (2006). The complicating factor of life cycles in corporate venturing. Entrepreneurship Theory and Practice, 30(6), 831-836. https://doi.org/10.1111/j.1540-6520.2006.00154.x

Hsu, L. C., \& Chang, H. C. (2011). The role of behavioral strategic controls in family firm innovation. Industry and Innovation, 18(7), 709-727. https://doi.org/10.1080/13662716.2011.604474

Ingram, A. E., Lewis, M. W., Barton, S., \& Gartner, W. B. (2014). Paradoxes and Innovation in Family Firms: The Role of Paradoxical Thinking. Entrepreneurship Theory and Practice, 40(1), 161-176. https://doi.org/10.1111/etap.12113

Jack, S. L., \& Anderson, A. R. (2002). The effects of embeddedness on the entrepreneurial process. Journal of Business Venturing, 17(5), 467-487. https://doi.org/10.1016/S0883-9026(01)00076-3

Jaskiewicz, P., Combs, J. G., \& Rau, S. B. (2015). Entrepreneurial legacy: Toward a theory of how some family firms nurture transgenerational entrepreneurship. Journal of Business Venturing, 30(1), 29-49. https://doi.org/10.1016/j.jbusvent.2014.07.001

Jick, T. D. (1979). Mixing qualitative and quantitative methods: Triangulation in action. Administrative Science Quarterly, 24, 602-611. https://doi.org/10.2307/2392366

Joardar, A., \& Wu, S. (2011). Examining the dual forces of individual entrepreneurial orientation and liability of foreignness on international entrepreneurs. Canadian Journal of Administrative Sciences/Revue Canadienne des Sciences de l'Administration, 28(3), 328-340. https://doi.org/10.1002/cjas.203

Johansson, A. W. (2004). Narrating the entrepreneur. International Small Business Journal, 22(3), 273-293. https://doi.org/10.1177/0266242604042379

Jonsen, K., \& Jehn, K. A. (2009). Using triangulation to validate themes in qualitative studies. Qualitative 
Research in Organizations and Management: An International Journal, 4(2), 123-150. http://dx.doi.org/10.1108/17465640910978391

Kammerlander, N., Dessì, C., Bird, M., Floris, M., \& Murru, A. (2015). The Impact of Shared Stories on Family Firm Innovation a multicase study. Family Business Review, 28(4), 332-354. https://doi.org/10.1177/0894486515607777

Kelly, L. M., Athanassiou, N., \& Crittenden, W. F. (2000). Founder centrality and strategic behavior in the family-owned firm. Entrepreneurship Theory \& Practice, 25(2), 27-42. https://doi.org/10.1177/104225870002500202

Kleinschmidt, E. J., \& Cooper, R. G. (1991). The impact of product innovativeness on performance. Journal of product innovation management, 8(4), 240-251. https://doi.org/10.1016/0737-6782(91)90046-2

König, A., Kammerlander, N., \& Enders, A. (2013). The family innovator's dilemma: how family influence affects the adoption of discontinuous technologies by incumbent firms. Academy of Management Review, 38(3), 418-441. https://doi.org/10.5465/amr.2011.0162

Kuhn, K. M., \& Galloway, T. L. (2015). With a little help from my competitors: Peer networking among artisan entrepreneurs. Entrepreneurship Theory and Practice, 39(3), 571-600. https://doi.org/10.1111/etap.12053

Labaki, R., Bernhard, F., \& Cailluet, L. (2019). The strategic use of historical narratives in the family business. In E. Memili \& C. Dibrell (Eds.), The Palgrave handbook of heterogeneity among family firms (pp. 531-553). Cham, Switzerland: Palgrave Macmillan.

Larty, J., \& Hamilton, E. (2011). Structural approaches to narrative analysis in entrepreneurship research: Exemplars from two researchers. International Small Business Journal, 29(3), 220-237. https://doi.org/10.1177/0266242611401796

Litz, R. A. (1997). The family firm's exclusion from business school research: Explaining the void; addressing the opportunity. Entrepreneurship Theory and Practice, 21(3), 55-71.

Litz, R. A., \& Kleysen, R. F. (2001). Your old men shall dream dreams, your young men shall see visions: Toward a theory of family firm innovation with help from the Brubeck family. Family Business Review, 14(4), 335-352. http://doi.org/10.1111/j.1741-6248.2001.00335.x

Lyotard, J. F. (1984). The postmodern condition: A report on knowledge (Vol. 10). Manchester, UK: Manchester University Press.

Mani, D., \& Durand, R. (2019). Family firms in the ownership network: Clustering, bridging and embeddedness. Entrepreneurship Theory and Practice, 43(2), 330-351. https://doi.org/10.1177/1042258718796082

McCollom, M. (1990). Problems and prospects in clinical research on family firms. Family Business Review, 3(3), 245-262. https://doi.org/10.1111/j.1741-6248.1990.00245.x

Nieto, M. J., Santamaria, L., \& Fernandez, Z. (2015). Understanding the innovation behavior of family firms. Journal of Small Business Management, 53(2), 382-399. https://doi.org/10.1111/jsbm.12075

Patton, M. Q. (1990). Qualitative evaluation and research methods. Newbury Park, CA: Sage.

Phan, P. H. (2004). Entrepreneurship theory: Possibilities and future directions. Journal of Business Venturing, 19(5), 617-620. https://doi.org/10.1016/j.jbusvent.2003.09.001

Pret, T., \& Cogan, A. (2018). Artisan entrepreneurship: a systematic literature review and research agenda. International Journal of Entrepreneurial Behavior \& Research, 25(4), 592-614. https://doi.org/10.1108/IJEBR-03-2018-0178

Ramadani, V., \& Hoy, F. (2015). Context and Uniqueness of Family Business. In L. P. Dana \& V. Ramadani (Eds.), Family businesses in transition economies: Management, succession and internationalization (pp.9-37). International Publishing Switzerland: Springer. https://doi.org/10.1007/978-3-319-14209-8

Ramadani, V., Hisrich, R. D., Dana, L. P., Palalic, R., \& Panthi, L. (2017). Beekeeping as a family artisan entrepreneurship business. International Journal of Entrepreneurial Behavior \& Research, 25(4), 717-730. https://doi.org/10.1108/IJEBR-07-2017-0245

Reay, T. (2019). Family routines and next-generation engagement in family firms. Entrepreneurship Theory and Practice, 43(2), 244-250. https://doi.org/10.1177/1042258718796083

Rogers, E. M. (1995). Diffusion of Innovations: modifications of a model for telecommunications. In M. W. Stoetzer \& A. Mahler (Eds.), Die Diffusion von Innovationen in der Telekommunikation. Heidelberg/New 
York, NY: Springer.

Russell, R. D. (2005). Cultural influences on entrepreneurship: implications for the emergence of new ventures in Latin America. Journal of Transnational Management, 10(1), 37-59. https://doi.org/10.1300/J482v10n01_04

Saxenian, A. (1994). Regional Advantage: Culture and Competition in Silicon Valley and Route 128. Cambridge, MA: Harvard University Press.

Sciascia, S., Mazzola, P., \& Chirico, F. (2013). Generational involvement in the top management team of family firms: Exploring nonlinear effects on entrepreneurial orientation. Entrepreneurship Theory and Practice, 37(1), 69-85. https://doi.org/10.1111/j.1540-6520.2012.00528.x

Sciascia, S., Nordqvist, M., Mazzola, P., \& De Massis, A. (2015). Family ownership and R\&D intensity in smalland medium-sized firms. Journal of product innovation management, 32(3), 349-360. https://doi.org/10.1111/jpim.12204

Sharma, P., \& Chrisman, J. J. (1999). Toward a reconciliation of the definitional issues in the field of corporate entrepreneurship. Entrepreneurship Theory \& Practice, 23(3), 11-27. https://doi.org/10.1177/104225879902300302

Sharma, P., \& Manikutty, S. (2005). Strategic divestments in family firms: Role of family structure and community culture. Entrepreneurship Theory and Practice, 29(3), 293-311. http://dx.doi.org/10.1111/j.1540-6520.2005.00084.x

Sharma, P., Chrisman, J. J., \& Chua, J. H. (2003). Predictors of satisfaction with the succession process in family firms. Journal of Business Venturing, 18(5), 667-687. https://doi.org/10.1016/S0883-9026(03)00015-6

Short, J. C., Ketchen D. J., \& CL, S. (2010). The concept of 'opportunity' in entrepreneurship research: Past accomplishments and future challenges. Journal of Management, 36(1), 40-65. https://doi.org/10.1177/0149206309342746

Sieger, P., \& Minola, T. (2017). The family's financial support as a "poisoned gift": A family embeddedness perspective on entrepreneurial intentions. Journal of Small Business Management, 55, 179-204. https://doi.org/10.1111/jsbm.12273

Stough, R., Welter, F., Block, J., Wennberg, K., \& Basco, R. (2015). Family business and regional science: "Bridging the gap". Journal of Family Business Strategy, 6(4), 208-218. http://dx.doi.org/10.1016/j.jfbs.2015.11.002

Suddaby, R., Bruton, G. D., \& Si, S. X. (2015). Entrepreneurship through a qualitative lens: Insights on the construction and/or discovery of entrepreneurial opportunity. Journal of Business Venturing, 30(1), 1-10. http://doi.org/10.1016/j.jbusvent.2014.09.003

Tagiuri, R., \& Davis, J. (1996). Bivalent attributes of the family firm. Family Business Review, 9(2), 199-208. https://doi.org/10.1111/j.1741-6248.1996.00199.x

Thornton, P. H., Ribeiro-Soriano, D., \& Urbano, D. (2011). Socio-cultural factors and entrepreneurial activity: An overview. International Small Business Journal, 29(2), 105-118. https://doi.org/10.1177/0266242610391930

Ucbasaran, D., Westhead, P., \& Wright, M. (2001). The focus of entrepreneurial research: contextual and process issues. Entrepreneurship Theory and Practice, 25(4), 57-80. https://doi.org/10.1177/104225870102500405

Upton, N., Teal, E. J., \& Felan, J. T. (2001). Strategic and business planning practices of fast growth family firms. Journal of Small Business Management, 39(1), 60-72. https://doi.org/10.1111/0447-2778.00006

Wiklund, J. (1998). Small firm growth and performance: Entrepreneurship and beyond. Jönköping University: Jönköping International Business School.

Yin, R. K. (2008). Case study research (4th ed.). Thousand Oaks, CA: Sage.

Zaheer S. S. A., \& A, Z. (1999). Time scales and organizational theory. Academy of Management Review, 24(4), 725-740. http://dx.doi.org/10.1177/2041386612442079

Zahra, S. A. (1991). Predictors and financial outcomes of corporate entrepreneurship: An exploratory study. Journal of Business Venturing, 6(4), 259-285. https://doi.org/10.1016/0883-9026(91)90019-A

Zahra, S. A. (2006). New venture strategy: Transforming caterpillars into butterflies. In S. Parker (Ed.), The Life Cycle of the Entrepreneurial Venture (pp. 39-76). Boston, MA: Kluwer. 
Zahra, S. A. (2012). Organizational learning and entrepreneurship in family firms: Exploring the moderating effect of ownership and cohesion. Small Business Economics, 38(1), 51-65. http://dx.doi.org/10.1007/s11187-010-9266-7

Zahra, S. A., \& Sharma, P. (2004). Family business research: A strategic reflection. Family Business Review, 17(4), 331-346. https://doi.org/10.1111/j.1741-6248.2004.00022.x

Zahra, S. A., \& Wright, M. (2011). Entrepreneurship's next act. Academy of management perspectives, 25(4), 67-83. http://dx.doi.org/10.5465/amp.2010.0149

Zahra, S. A., Hayton, J. C., Neubaum, D. O., Dibrell, C., \& Craig, J. (2008). Culture of family commitment and strategic flexibility: The moderating effect of stewardship. Entrepreneurship Theory and Practice, 32(6), 1035-1054. https://doi.org/10.1111/j.1540-6520.2008.00271.x

Zellweger, T. M., Nason, R. S., \& Nordqvist, M. (2012). From longevity of firms to transgenerational entrepreneurship of families introducing family entrepreneurial orientation. Family Business Review, 25(2), 136-155. https://doi.org/10.1177/0894486511423531

\section{Copyrights}

Copyright for this article is retained by the author(s), with first publication rights granted to the journal.

This is an open-access article distributed under the terms and conditions of the Creative Commons Attribution license (http://creativecommons.org/licenses/by/4.0/). 